\title{
ON THE ERZA-MORDVINIAN BIRTH CUSTOMS IN SABAJEVO AND POVODIMOVO VILLAGES
}

\section{Marika Mikkor}

During 1984-1989 I interviewed women in the Estonian villages at the coast of the Black Sea in the Caucasus, in Estonia, Ingria and Mordvinia on the topic of birth traditions. The accumulated material has been compiled into an overview of the birth traditions of the Izhorians of the Soikkola Peninsula (Mikkor 1999a) and the Finnish of the Kurgola Peninsula, as well as of the beliefs related to childbearing and midwifery (obstetrics) of the Caucasian Estonians (Mikkor 1996, 1998a, 1999b). In 1988 and 1989 I collected material on life's notable days in the Erza-Mordvinian villages of Sabajevo and Povodimovo; the recorded accounts have resulted in an article about the burial and birth customs in the villages (Mikkor 1994, 1998b).

Both Sabajevo and Povodimovo are located in a region with a relatively mono-ethnic population where the Erza folk culture has survived for the longest time. This characterisation is most typical to Sabajevo village where the traditional folk costumes were worn at festive rituals as late as in 1980s. Povodimovo was considerably more "urbanised" than Sabajevo: instead of the rustic wooden cottages people often built brick houses, the tradition of wearing traditional costumes became obsolete already in 1920s-1930s, also, the dialect of Erza villagers contained a larger number of Russian loan words.

\section{PREGNANCY}

As to the pregnancy (pesksesa Sabajevo, pekshesa Povodimovo) I formed questions on the restraints laid on and advice given to pregnant women and on predictions about the sex of the future child. I based my questions on the traditional concepts of the Estonian birth customs. In both villages a pregnant woman (pokshpekie Sabajevo, pekiv Povodimovo) was allowed to attend weddings and funerals. 


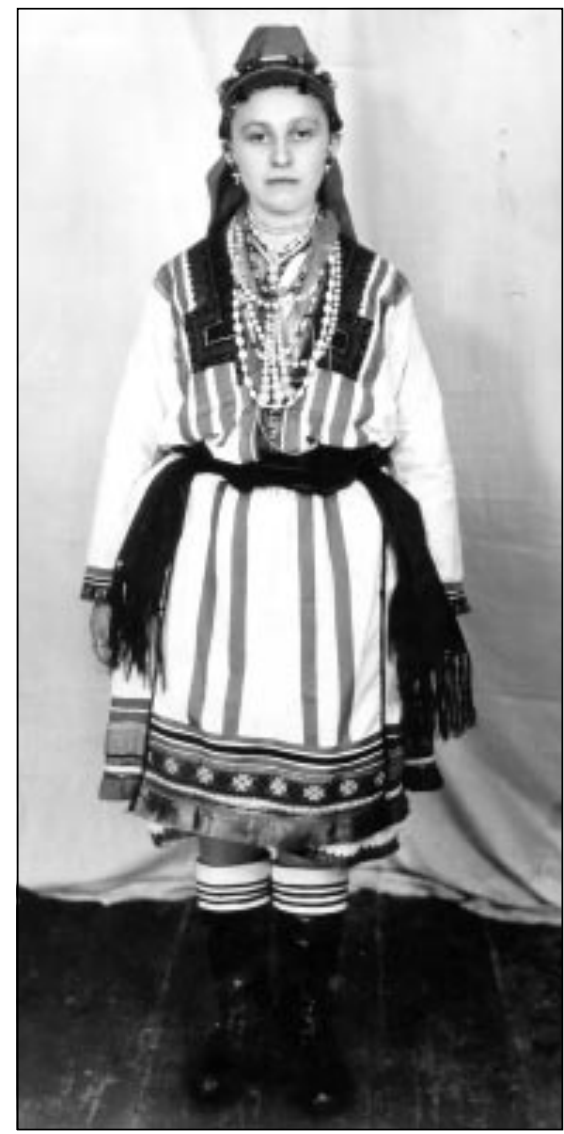

A woman in a folk costume, nowadays used as a ritual garment of wedding hostess at Sabajevo village, 1980 s. From a private photo collection.

Startling a woman could result in the birth of a premature, stuttering or otherwise backward child, or a child with an eye disease (EA 218: 71, 112; EA 218: 303-304). Also, the excessive alcoholism of women caused birth defects on children (EA 218: 70-71). Generally, however, no cases of "startling" were known or remembered by the respondents, although in, for example Estonian folk tradition it is mentioned fairly often. Only one woman from Povodimovo knew that if a pregnant woman was startled by seeing a fire and happened to touch herself at the same time, a child got a mark - piatno - at the same place (EA 218: 250). Other respondents had not heard of or could not remember this universally common belief: on one occasion a person assumed that being startled by a fire could result in the birth of a freak or miscarriage (EA 218: 112). Two respondents from Sabajevo said that an expecting mother was not allowed to kick a cat or a dog; only one of them knew that in folk tradition the restraint was explained by the fact that it could result in the birth of a hairy child (EA 218: 71, 131).

While in Sabajevo and Povodimovo no startling "defects" were described except on few occasions and no signs of startling were known, both the Finnish of the Kurgola Peninsula as well as the Izhorians of the Soikkola Peninsula in Ingria were well aware of 
the "fire-marks" (Mikkor 1999a: 976-977). The response of the orthodox Izhorians to the questions about other "defects" was often a mere "only God knows and can do everything". The direct questions about the "snake defects" that are still known in Estonia were answered by the Izhorians' statement that "he who kills a snake will be absolved of nine sins". The ignorance of the startling defects might be caused by the influence of the Orthodox doctrines. In Estonia people still know and believe in them to the present day; also, more accounts on the subject have been collected here than from the Caucasian Estonians (Mikkor 1996: 68-70).

A 77 year-old Varvara Pinjaskina from Sabajevo recalled a restraint that a pregnant woman was not allowed to weave linen cloth for then the child's legs will be bandy or his face will have marks (EA 218: 131). Other restraints on the expecting women were not mentioned. They did not even believe in the danger of watching the slaughtering of an animal (EA 220: 130). In Sabajevo, a pregnant woman could even decapitate a chicken herself (EA 218: 112, 130).

The sex of a child was predicted on the woman's face and the shape of her belly. A prevalent belief in Sabajevo was that a woman's fine, clean and fresh complexion denoted the birth of a daughter, and a face changed by pregnancy meant the birth of a son (EA 218: 70, $113,130,131)$. One woman, however, knew it the other way round saying that the "distorted" face predicted the birth of a daughter and the fine face that of a son (EA 218: 70). In Povodimovo, too, the respondents agreed that an ugly spotted face told of the birth of a daughter, and a normal unchanged face denoted a son (EA 218: $250,296,303)$. Some women admitted this to be true (EA 218: 296), others did not (EA 218: 250). The respondents in both villages considered a wide belly as a sign of the birth of a daughter and a pointed salient belly a sign of a son (EA 218: 70, 113; EA 218: 296, 303). Few statements, however, contradicted the belief. Nevertheless, such beliefs are universal.

During the pregnancy it was not allowed to make clothes for the baby so that nothing would happen to it. 


\section{CHILDBIRTH}

It is said that in earlier times people were more able and children were born even at one's daily work on the field. Nowadays women are said to be "as unwell as frogs". Until 1930s - 1940s woman gave birth to children in a farmhouse during cold periods and sauna or a horse stable during summer (EA 218: 72, 133, 252, 305).

During delivery women were mostly lying on straws laid on the floor. An account from both villages tells of the kneeling position (EA 218: 133, 253); in Povodimovo it was said that women were on their knees only during a very easy delivery. In time delivery in bed became more common, whereas the respondents of Povodimovo emphasised that the beds were also made of straw. A woman from Sabajevo who had delivered her children in bed said that the easier births were delivered on the floor (EA 218: 133). The lasting of the more traditional ways of childbirth (in the kneeling position and on the floor) at easier deliveries could be explained by the fact that in easier cases no professional help was needed whereas in more complicated cases a professional midwife suggested lying in bed during labour.

During the process a woman wore a shirt and a kerchief or a traditional costume head-dress (EA 218: 74, 82), on her plaited hair (EA 218: 252). The kerchief was cast off only after a longer suffering in pangs. It was a remnant of an old custom to open all the knots and plaits of a woman in childbed (Fedianovich 1981: 118) was known in Mordvinia as well as in the rest of the world. In Ingria the custom was alive as late as in 1960s (EA 234: 302; Mikkor 1999a: 979).

The woman in labour was assisted by an elderly village woman bapka or baabushka who had to deliver the child, cut through and tie the umbilical cord. In necessity, some bapkas could even change the position of the baby or help it out with their hands (EA 218: 73-74, 305). If placenta would not part by itself a woman was given some sweet or soda water to drink (EA 218: 74), her belly was massaged, and if that did not help, the placenta was taken out by hand (EA 218: 253). 
Sometimes the child's body or face was covered by the pieces amnion (in Estonia often known as the "lucky shirt" or the caul). In Sabajevo it was called tshaamaks, in Povodimovo shartshau. The Sabajevo people believed that a tshaamaks could bring along both luck and misfortune (EA 218: 73, 82, 133). If looking through it at the sun an eagle was seen on the "shirt", it meant luck, whereas for some "shirts" (it is not known which, though) it was said that the child will not live long (EA 218: 73). Similarly to most birth-related beliefs, beliefs about the "lucky shirt" or caul are universal. The belief in the unhappy fate of the child was less common: it was thought, for example, that the red colour of the caul denoted luck and the black colour denoted misfortune (Hovorka \& Kronfeld 1909: 593; Ruotsalainen 1950: 188; Koivu 1962: 303, 306). In Sabajevo, the "caul" was wrapped in paper and hidden in a closet so that noone could steal it. A tshaamaks functioned as an amulet and was taken along to the market or for selling fire-wood at a fair, etc. for luck (EA 218: 133). If it happened to be stolen, the thief would get all the luck (EA 218: 73). In 1950s a Sabajevo woman delivered

Sjupavon from Sabajevo bore three children in caul during 1940-1950. Photo by Riin Alatalu, 1989. Photo collections of ENM 2309: 25.

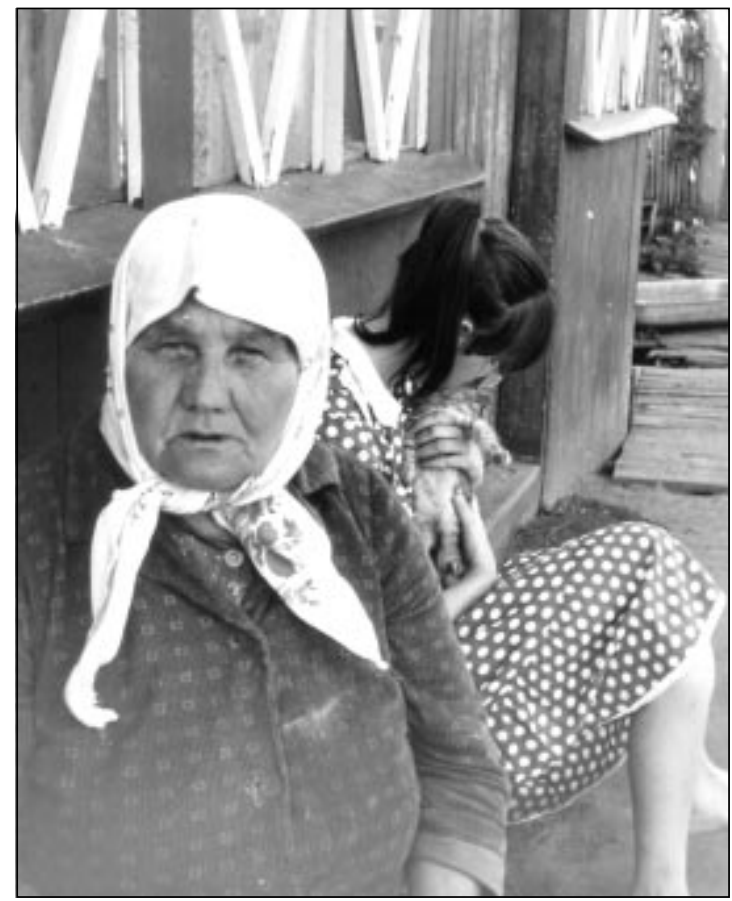


three children with a tshaamaks. The umbilical cord used to be kept wrapped in a piece of cloth near the cradle or under the child's pillow (EA 218: 133).

In Povodimovo a shartshau was generally considered as a sign of luck; only one respondent knew that it could also bring misfortune (EA 218: 306).According to one respondent the shartshau with placenta were buried (EA 218: 298), but in most cases it was dried, wrapped in a small pouch and placed around the child's neck with a cross. When a girl happened to get married the caul was sewn into her kikirka i.e. into the brim of her head-cover, whereas when a boy got married it was sewn into his coat (EA 218: 298-299, 306). The amulet was believed to protect from misfortune and brought along success. In Povodimovo it was thought that if the shartshau was stolen or its owner lost it, the luck was gone and its new owner got all the luck. A 60 year-old Anna Burnajeva told me in earnest that she had kept her son's caul in a chest of clothes but the amulet was lost and her son's success with it. Nowadays, women are worried that while delivering a child in a modern hospital they are not given the caul or it might be stolen (EA 218: 298, 306).

All over the world people have carried the caul around their necks as an amulet (Ploss 1884: 12-15; Zelenin 1927: 293; Pelkonen 1931: 216; Ruotsalainen 1950: 171, 176; Chursin 1956: 182; Koivu 1962: 305; Maslova 1984: 102), and it is also believed that if it was taken by someone else their success and luck is also gone. Therefore, women took extra care to be certain that the midwives attending birth could not steal the caul to sell it afterwards (Loorits 1932: 146; Ruotsalainen 1950: 178, 188). The caul-related beliefs were very common among the upper society as well as town-people. It is known that the magistrates in Ancient Rome used to procure themselves the cauls, and in the earlier centuries European newspapers printed advertisements about buying a caul (Ploss 1884: 14; Hovorka \& Kronfeld 1909: 593). Also, as late as in the middle of the last century Russian noblemen used to borrow a caul for the more important business deals if they themselves did not happen to have it (Sumtsov 1880: 79). In the Erza tradition the significance lies in the fact that the beliefs have been kept alive till the present day. Sewing the caul in clothes kept it from getting lost: similar custom was known elsewhere. In Norway, for example, such 
amulets were worn around the neck, or implanted in a person's body as late as during WW 1 (Ruotsalainen 1950: 175, 176, 179, 184). The use of amulets by other members of the family for luck at some event, say, at the court was also common (Soloviova 1983: $126,127)$. In Ingria it was practised as late as at the end of $1930 \mathrm{~s}$ (Mikkor 1999a: 983; Päss 1938: 542).

A umbilical cord wrapped around the child's neck denoted either luck or misfortune (EA 218: 298). Older people often noted that the children born on Monday were unlucky for the rest of their lives. The best day for being born was Sunday (EA 218: 72-73).

Placenta (eidindodu(ne), known in Sabajevo as "the child's pillow") was wrapped in a piece of cloth, placed in a birch-bark shoe (often with a bread crumb) and buried mostly under the farm-room's floor so that a stranger, like a witch, could not find it. Sometimes it was buried also in the farmyard. One respondent said that it was buried under the floor during winters as "there is no place for that in the garden then" (EA 218: 73, 80, 82, 114). In Povodimovo the placenta was buried so that "it would not lie around" and no-one could steal it (EA 218: 252, 298, 305). A 66 year-old Ljubov Saigachova said that a baabushka could steal the eidindodune to feed it in a meat-pie to a sterile woman so that she could have children, whereas the rightful owner of the placenta would become infertile (EA 218: 299). Anna Burnaieva knew that a childless woman should eat a dried placenta. Another efficient treatment for infertility was thought to be whisking in sauna. The use of placenta for curing sterility is mentioned in other Mordvinian tradition accounts as well, and earlier, people were afraid that a person assisting the birth or a sterile woman might steal it (Fedianovich 1979: 80; Beliaieva 1982: 56).

Placenta has been used in folk medicine all over the world for a long time: usually, it was dried and fed to the sick to treat several diseases (Hovorka \& Kronfeld 1909: 590; Pelkonen 1931: 228). After delivery the mother's and the child's face were wiped with placenta, particularly when there were marks or something similar on their faces (Pelkonen 1931: 222; Loorits 1932: 144; Karely 1983: 145). Sterility has been cured with placenta in the Arab countries as well as in Serbia. An infertile Arab woman had to dig out the placenta, soak it in the water and wash herself with it (Granqvist 
1947: 98), in Serbia fresh placenta was used for that purpose (Hovorka \& Kronfeld 1909: 516). The Russians and the Rumanians believed that an infertile woman had to eat the end of the umbilical cord (Hovorka \& Kronfeld 1909: 517; Zelenin 1927: 293), whereas in Estonia infertility was cured by drinking the navel blood of the new-born baby (ERA II 187, 516 (57) < Kaarma; ERA II 193, 360 (76) < Põltsamaa).

In fact, placenta is ate even in contemporary Europe. For example, a Finnish acquaintace of mine living in Switzerland did so by the advice of the midwife in 1989. She gave birth at home.

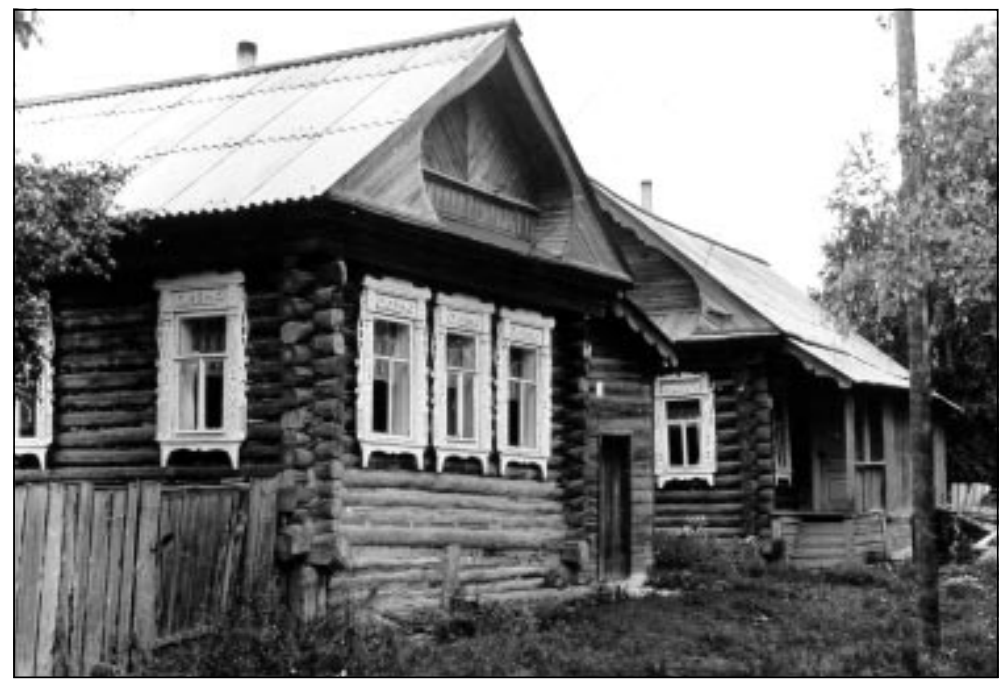

In Povodimovo there were exquisite log houses with ornate window frames. Photo by Jüri Karm, 1989. Photo collections of ENM 2332: 76.

The custom of burying or hiding placenta in the farmyard or a house was also known all over the world, in several traditions different models of behaviour were applied simultaneously. Placenta placed in a birch-bark shoe was buried under the floor also by the Russians (Fedianovich 1979: 81; Beliaieva 1982: 56; Zelenin 1927: 293), whereas the Izhorians and the Setu buried it under the floor wrapped in a clean piece of cloth (Mikkor 1999a: 984; Väisänen 1924: 202). The Russians (Zelenin 1927: 293; Maslova 1984: 109) 
and also Estonians (ERA II 283, 281/3 (46 ja 52) < Rapla; ERA II $22,138 / 9(18)<$ Urvaste) buried the placenta together with some money, bread and eggs, etc. The Livonians were also known to have buried it under the farm-room's floor (Loorits1932: 144). In brief, the custom of burying placenta could be explained by the need to "protect the child and its mother" (Grünthal 1924: 389, 390). People have believed that a placenta is a part of the child who could therefore be harmed through it (Talve 1979: 174). The Arab people believed that mistreating placenta could make a woman sterile. Therefore they took care to prevent the placenta from being eaten by cats or stepped over as it might have resulted in the future sterility of a woman (Granqvist 1947: 97-98). In Estonia, Finland and elsewhere people tried to bring along or control birth by burying the placenta in a certain way. If it was buried with the umbilical cord pointing upward the woman would remain fertile, if the cord pointed downward she would become sterile (Sumtsov 1880: 80; Grünthal 1924: 305; Pelkonen 1931: 224, 230).

The folk tradition of other peoples does not mention the concern about it being stolen, in most cases it was buried in order to prevent from being eaten by animals (dogs, cats, wild animals) or being walked on it (Väisänen 1924: 202; Grünthal 1924: 389; Pelkonen 1931: 223, 224; Pchelina 1937: 92; Granqvist 1947: 98; Grundström 1953: 88). In fact, the beliefs concerning placenta are very versatile indeed, different peoples either bury or burn or cast it in a running water (Sartori 1910: 23), some peoples dry it, wrap it in a cloth and keep it in the cradle to "keep the baby healthy" (Pelkonen 1931: 223; see also Granqvist 1947: 74). In some regions the Lapps have fed placenta to the dogs (Itkonen 1948: 387), some peoples have cast it to the woods or buried or taken it at the waters (Pelkonen 1931: 224; Itkonen 1948: 392). Placing a stone on the burial place protected placenta from being eaten by the animals (Grünthal 1924: 389; Pchelina 1937: 92; Grundström 1953: 88).

In Sabajevo, the new-born child was slightly bathed in a clean (soapless) warm water, the water was poured to the farmyard's corner (EA 218: 80) or under the apple-tree (EA 218: 74), never to a place where people walked over. On three days following the childbirth the mother went to bathe and whisk herself and her baby in the sauna (EA 218: 74, 80, 135). 
In Povodimovo, a 75 year-old Darja Beliaieva recalled that in 1930s1940 s a mother took her baby and went to the sauna right after giving birth and put on clean clothes after bathing (EA 218: 254). A 66 year-old Ljubov Saigachova told that a new-born child was not washed: it was wrapped in clothes and only in a day or two its mother took it to the sauna (EA 218: 300). The respondent herself had given birth to her children in a hospital during 1940s-1950s. Today, when the child is born at a hospital, the mother and the child have to go to bathe and whisk in the sauna right after they get home, so that the latter would sleep better (EA 218: 300). Until its fourth month a child is bathed every night, later on only at certain sauna-days, whereas no soap was used. In Povodimovo the

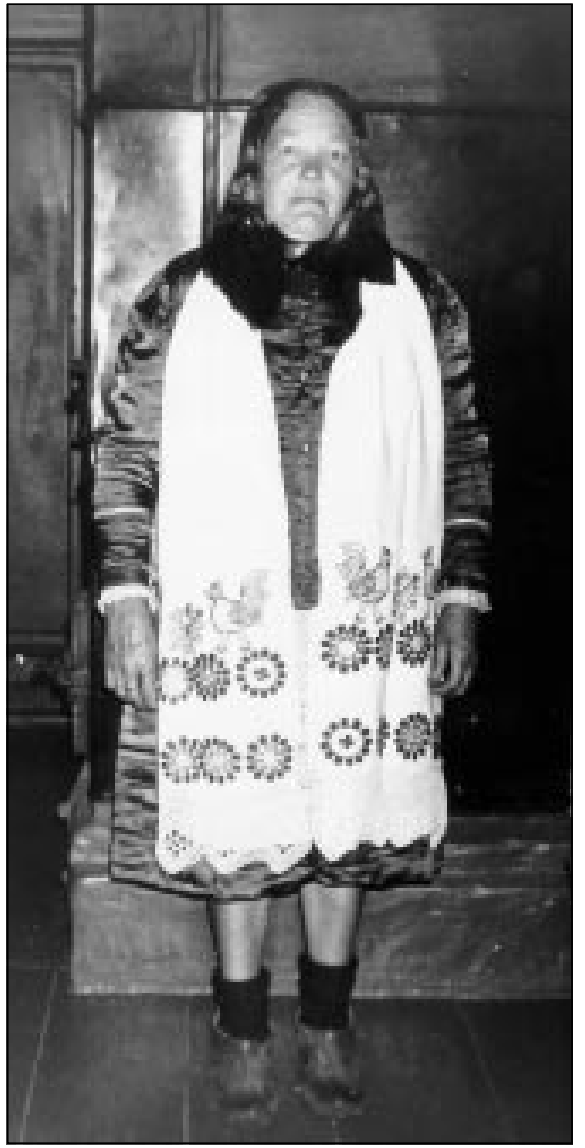
bathing water was poured to a "sacred" spot at the housewall in the farmyard, to the paazauugol, or the "sacred corner", "so that noone would step on the place or pour waste water" (EA 218: 301, 306). In Povodimovo the child's bathing water was sometimes poured also under a fruit tree - an apple or a cherry tree.

The custom of purifying the child and its mother by whisking and bathing in the sauna during three days following the birth was substituted by taking the mother and her child to the sauna right after their getting out of the hospital elsewhere in Mordvinia as well (Fediano-

Anja from Povodimovo in the ritual clothing of wedding hostess, wearing an iconic scarf around the neck. Photo by Riin Alatalu, 1989. Private photo collection. 
vich 1979: 86; 1981: 119; Beliaieva 1982: 57). In earlier times the bathing of a child and its mother was common for several other peoples: in the Setu and Karelian regions they were taken to the sauna after two or three days, health conditions permitting (Väisänen 1924: 203; Karely 1983: 145), whereas the Karelians had to heat the sauna three days in a row (Virtaranta 1961: 199; see also Leskinen \& Syrjänen-Kaukoranta 1939: 213). The Russian women had to go to the sauna (or an oven) to whisk and bathe the baby at the day of birth even if they were still weak; going to the sauna for at least three times in a row was almost compulsory (Popov 1903: 352). In Estonia, the woman was washed all over the body and dressed in clean clothes only on the third day following the delivery (Grünthal 1924: 392). An account from the 19th century says that after baptising the child the whole family went to the sauna, and the father of the child was whisked the hardest. The account does not mention any special treatment of the mother or the child, though (Luce 1827: 96; Wiedemann 1876: 308).

When a new baby was born in the family the other children of the family were told that the child was bought at a market (earlier) or the hospital (more recently). In Sabajevo, babies were also "found" in the nettles (EA 218: 76, 114, 115). Akulina Uchaikina from Sabajevo village said that if her mother gave birth to a child on a floor in 1930s, the elder children could watch in the same room (EA 218: 115). Today, small children at the age of 3 or 4 are said to know where the babies come.

\section{POSTNATAL PERIOD}

When a woman from Povodimovo village delivered her child in the sauna, she went to the farmhouse after the birth and for a week had to lie on the oven with her child. In some families a woman had to start a fire in the oven or do other housework right after the delivery, but if she had a loving and helpful husband or mother-inlaw she could rest for a few days. During six weeks, or the childbed period, she had no restraints except for going to church. In Sabajevo people told that a woman took her child and went to work at the field already on the day following childbirth (EA 218: 77, 80). The 
Erzas did not referre to the compulsory childbed period, which was known in Ingria until 1980s (Mikkor 1999a: 985).

The child was breastfed right after birth; the nursing lasted for 15 years. Children were rarely given cow-milk, they suckled it from the cow's horn (skalynsiuury in Povodimovo). At more recent hospital births the child was breastfed only on the third day following the birth (EA 218: 74). During 1980s younger mothers often nursed their children less than half a year. In Sabajevo, it was believed that the child could be weaned at any time, whereas in Povodimovo children were weaned only during colder seasons (early spring, autumn or winter) as it was believed that weaning a child in summer might make it sick. The weaning began usually on a Sunday or a Tuesday. The mother's breasts were rubbed in with pepper or made otherwise dirty and ugly. Some children paid no attention to it, wiped the nipples clean and suckled on (EA 218: 255). During the weaning period a child was sometimes taken to its grandparents for a few days (EA 218: 76). In addition to breast and cow-milk the

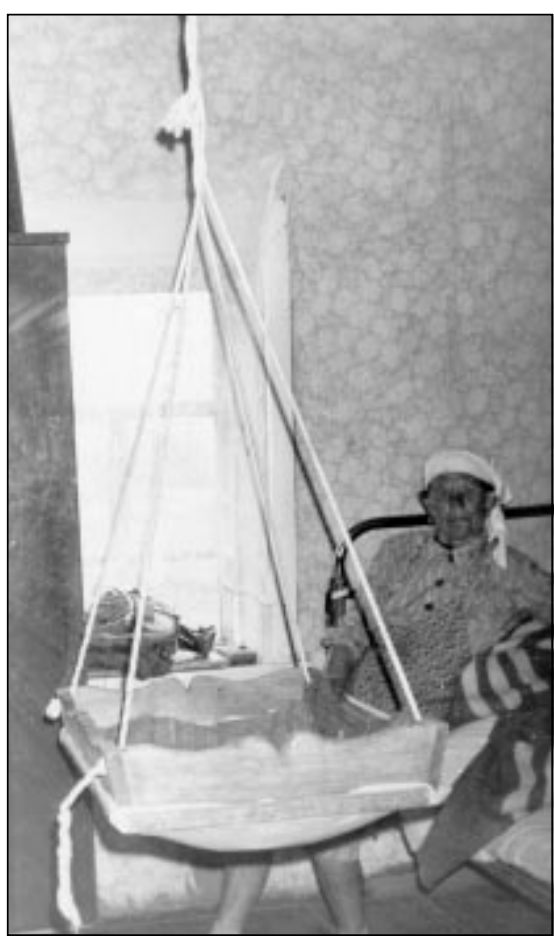
children were given a $k$ sin soska, or a "bread nipple" made of a piece of cheesecloth containing sugar and chewed bread to suckle. In Sabajevo it was practised until 1960s, in Povodimovo until 1950s (EA 218: 76, 137).

The accounts from both villages said that children were swaddled freely, and the swaddle-belts so common among other peoples were not known. At later hospital births children were also swaddled tighter. The cradle (lavs) had wooden

Hanging cradle in Sabajevo. Cradles can also be seen in houses with already grown-up children for cradles are used as swings by grandchildren. Photo by Riin Alatalu, 1989. Photo collections of ENM 2309: 35. 
sides and linen (or a hemp-fibre) cloth bottom, and it was hung to the ceiling by the four ropes fixed to its four corners.

In Sabajevo, a child was kept in dark for six weeks up the 1930s 1940s. A lavslanga, i.e. the cover was hung over the cradle (EA 218: 75, 81, 116). Even in more recent years the older people advised to keep the baby in the dark to protect it from the "evil eye". If a child had been cast an evil eye, or shelmytsyi, an old wise woman was called who put a protective spell on the child's clothes and the water sprinkled on it.

In Povodimovo, the covered cradle (lavsrutsia) was kept in a shady place; later it was explained by preventing the child from "getting bitten by the flies" (EA 218: 300). Originally, though, the child was hidden from the evil eye as well. If a person with an evil eye (peränshiälmä) cast a glance at the child, it became sick and refused to suckle. For curing the child, the old wise woman threw charcoal into water and said a spell on the water and a clean shirt. Then the child was washed with the water and dressed in the shirt (EA 218: 257, 301). A child could become troubled even if its clothes were drying outside and someone happened to steal its clothes.

In Ingria, the customs described above were kept alive for a long time. The Izhorians of the Soikkola Peninsula kept the child in a covered and dark cradle for six weeks as late as in 1940s, either for keeping the child more calm or protecting it from the evil eye. Even today people were afraid of an evil eye, in 1980s, for example, a child under a year was not shown to the strangers in Shavimäe village for same reason (Mikkor 1999a: 988). A new-born baby was not shown to village people in Estonia either (Boecler \& Kreutzwald 1854: 61; Jung 1879: 106; Grünthal 1924: 394). In different traditions the child was hidden from strangers for a shorter or a longer period of time, be it during pre-baptising period, or forty or seven days after its birth (Boecler \& Kreutzwald 1854: 61; Balov 1890: 95; Redko 1899: 63, 73; Sartori 1910: 27; Grünthal 1924: 443; Ruuttu 1931: 45; Päss 1938: 544, 559; Jordan 1978: 29; Pchelintseva 1987: 39). Among other peoples the child's clothes were never left outside to dry before baptising or during 6 weeks after the child's birth for the same reason (Paulaharju 1929: 16; Loorits 1932: 156; Grundström 1953: 88). Even in 1980s people in Shavimäe village thought that the clothes of a child under a year could not be dried outside 
(EA 234: 305-306). In some cases it was not allowed at nights (Grünthal 1924: 478; Väisänen 1924: 203), as the period after sunset was considered particularly dangerous for several other activities as well (Melik-Shakhnazarov 1893: 196; Grünthal 1924: 486; Granqvist 1947: 94; Karely 1983: 145; Dbar 1984: 165-166). The Caucasian Estonians considered such beliefs as most typical to the Russians and the "darker" people, while in earlier days it was not allowed to leave child's clothes outside even in Estonia (RKM II 22, 70 (23) < Räpina; RKM II 94, 104 (27) < Karksi).

In Sabajevo child's clothes were not left out for night (i.e., after nine o'clock in the evening) either in the fear of evil people and spells (EA 218: 75). The respondents in Sabajevo told that a child under the age of six months was endangered by vedun $\mathrm{s}$.Vedun is a soul of an evil person who left the body during her sleep. An evil

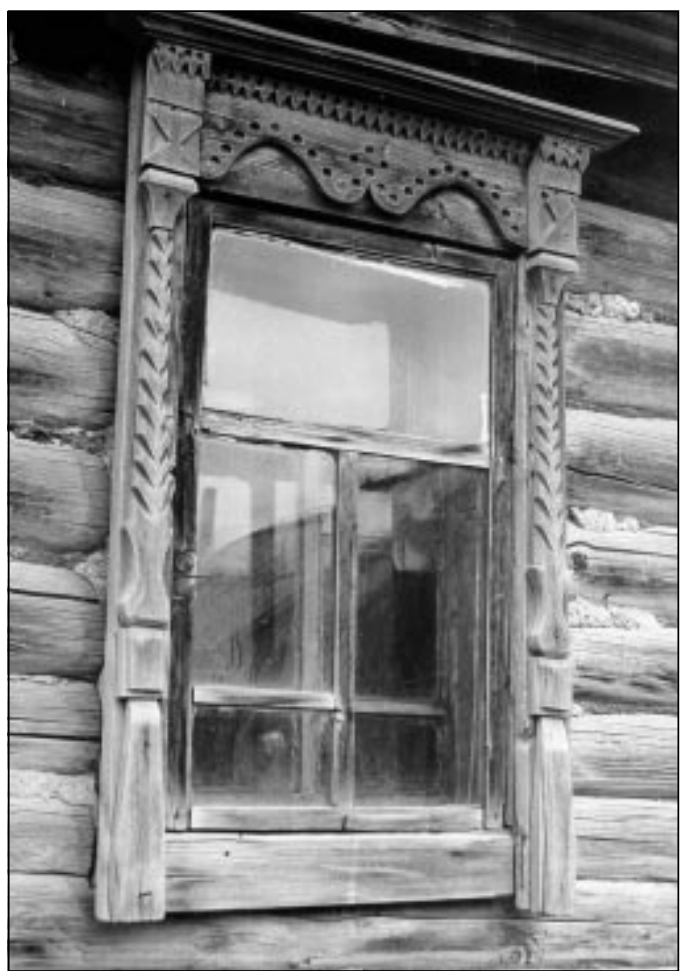

Ornamented window at Povodimovo. Photo by Jüri Karm, 1989. Photo collections of ENM 2332:79. 
old woman could sleep in the neighbouring house and during her sound sleep her soul was said to eat the child's soul. Vedun was thought to be invisible, it was also believed that it flies as a blueish flame around the new-born child's house (EA 218: 75, 136). To protect the child from vedun people had to throw bread into the burning oven, or place scissors at its pillow and protective herbs near the window (EA 218: 136). My conversation with village women left the impression that they truly believed in the onetime existence of vedun, they concluded the subject with an additional comment that they do not exist any more. The Mordvin veduns appear in earlier material as well: during the past century in Saratov province, for example, the newborn child had an armed guardian six weeks after its baptising, putting the child to bed her mother made a cross sign in the air with a knife and tucked it then under the child's pillow (Redko 1899: 74, 75). People were afraid that avedun might eat the child's heart.

Beliefs about the evil spirits lurking around new-born children are known in the whole world. Among different peoples they were believed to appear in the shape of a human (say, an old woman) or an animal (a snake, for example), they could be invisible and could change a child or cause its death (Ploss 1884: 111-112; Redko 1899: 65-75). In Estonia, for instance, people believed that the Vanapagan, or Devil, could change a new-born baby (Grünthal 1924: 387 ). Sometimes both the child and its mother were considered to be in danger, sometimes only one of them. The child was protected against evil spirits and evil eye by placing iron cutlery (a knife, a nail, scissors, sheep shears) (Boecler \& Kreutzwald 1854: 60; Ploss 1884: 121, 122; Mashurko 1894: 306; Redko 1899: 75; Zelenin 1927: 293; Eisen 1928: 433; Paulaharju 1929: 15; Pchelina 1937: 94-95; Karely 1983: 145; Maslova 1984: 109; Pchelintseva 1987: 41) or bread under the child's pillow (Pchelintseva 1987: 41). Other peoples, too, use several herbs for keeping the evil away (Zelenin 1927: 293). A woman in childbed could also be protected by iron cutlery, garlic garlands, etc. Often the cutlery is placed on the threshold of the house. The evil spirits were kept away by a fire burning through the night; it was believed to have protective powers among others by the Estonians, Latvians, Belorussians, Lithuanians as well as the Germans (Sumtsov 1880: 81; Redko 1899: 75). 
The protective force of the fire is also universally known. The overnight watch of a child or a woman in childbed is less common, but has been mentioned in the traditions of the South-Slavic people, Jews, Georgians as well as the Mordvins (Ploss 1884: 125; Redko 1899: $65,71,74)$. While the Christian peoples considered the days before baptising as the most dangerous period, the Mordvins used to watch the child for a particularly long period.

During the six weeks after childbirth a Sabajevo woman in childbed was visited by her married female relatives, who brought along food. The custom was called vartshamo or vartshama. Earlier, each visitor took the woman two eggs and a home-made loaf of bread (EA 218: 77, 118), sometimes also pies and onions have been mentioned (EA 218: 117, 138). In Povodimovo the woman was visited only by her closest female relatives, her mother and sister(s). It was not a cause for a social gathering, in fact, this was not even allowed. Friends and relatives gathered only for the child's baptising (EA 218: 258, 302, 307). Nowadays, the woman released from the hospital is visited mostly by her female friends.

Heikinmäki has considered a general custom at visiting a woman in childbed that all the other married women took her food during the period she was considered filthy and was restricted from doing housework or cooking (1968: 231-233). The Erza-Mordvinian tradition saw that when a woman stayed in the sauna for 3-7 days after childbirth, then her relatives brought her food there (Fedianovich 1979: 82). In Mordvinia a praying ceremony for closer relatives was organised at the day or the day following the birth, where people brought wheat flour, barley, eggs and other food stuff (Fedianovich 1979: 86; Beliaieva 1982: 57-58). During the ceremony, a god-father and a god-mother were appointed, who had to come back the following day and bring more food (Beliaieva 1982: 5758). Thus, in some places the bringing of food was connected to baptising. At the baptising the woman, in turn, had to offer gifts to her husband's relatives (Fedianovich 1979: 83).

Among the other peoples the woman in childbed was first congratulated by the closest female relatives (Soloviova 1987: 32), relatives (Väisänen 1924: 204; Itkonen 1948: 394), relatives and neighbours (Murathan 1937: 72; Päss 1938: 544; Chursin 1956: 183; Karely 1983: 145) or just women (Zelenin 1927: 194; Talve 1979: 175) who 
brought along gifts and food. In some cases the number of participants was smaller, in some cases bigger. While the most traditional visitors were married women in their fertile years, among the members of a mountain tribe Hevsurs in Georgia it was the elderly women who could not bear children any more or small girls who took food to the woman lying in childbed in a small cabin outside the village. They tried to avoid any contact with the woman, leaving the food near the cabin or passing it to her through a special opening (Redko 1899: 113). The child's family held a smaller party for the relatives, sometimes also for the neighbours, who again had to bring gifts (Sumtsov 1880: 85; Redko 1899: 75; Sohlman 1933: 162; Harva 1935: 67-68; Talve 1959: 1-5). Among some Siberian peoples such parties were attended only by the closest relatives, sometimes only by women (Harva 1933: 120). The Georgians cooked a ritual sweet wheat or corn flour porridge and offered it to the woman in childbed, midwife and all the other women who attended the birth, the custom was called "treating the knee". During the next day the porridge was offered to all the family, both male and female, as well as to the congratulating guests (Soloviova 1983: 127; Soloviova 1987: 31). A similar ritual meal was offered to the midwife and attendants also by the Maya Indians (Jordan 1978: 15).

Until the middle of 1920 s the children of Sabajevo and Povodimovo were baptised $^{1}$ at the age of a few days or a week. As the churches were destroyed, children were later baptised also by village women and a priest who visited the villages occasionally until 1930s. The god-mother (krosnava in Sabajevo and krostnyiava in Povodimovo) and the god-father (krostntentia in Sabajevo and krostnyitiatia in Povodimovo) were mostly from the closest family circle, the child's aunts or uncles. In Povodimovo the god-mother was chosen from the maternal relatives and the god-father from among the paternal relatives. God parents could be even children between the age of five to ten. Varvara Pinjaskina who was born in Sabajevo in 1911 became a god-mother at the age of eight (EA 218: 139), Darja Beliaieva born in Povodimovo in 1914 at the age of ten when attending her brother's child baptising (EA 218: 260). In places, young children at the age of 10-12 were chosen godparents among the Russians as well (Haruzina 1906: 90). In Ingria, for instance, the godparents were young boys and girls at the age of 13-14 (Päss 1938: 557). 
The child's mother did not attend the baptising ceremony. The god son krostnyisioram was baptised in his god-father's arms, the god son krostnaiadotsh in the arms of her god-mother. The god-father had to buy the cross, the god-mother the baptismal cloth (riiza) where the child was wrapped after the ceremony. After baptising the cross was hung around the child's neck and it was dressed in its first shirt. The name of the child was taken from a church register. In Povodimovo a feast kstinia was held to celebrate the baptising, where the guests had to bring apples, nuts, pies, buns and jam. ${ }^{2}$ Ljubov Saigachova who was born in 1923 told that a pie covered with a child's shirt or cap was taken to the baptismal feast (EA 218: 302). Nowadays the guests bring expensive gifts as well as money to the party. In Sabajevo, however, no gifts were taken to the baptising ceremony.

\section{IN CONCLUSION}

Birth customs as well as all the other customs related to the most notable days of one's life contain many universal and generally popular elements. They include versatile and often contradicting beliefs and habits, often simplified and evened by the researchers and narrators who tend to focus on the customs they know more about or occur to them first. Thus, different accounts tell us about different customs. Therefore, the comparison between the customs of a given ethnic group could be carried out only on the basis of the wider and more general background. The only significant fact in the Erza-Mordvinian birth tradition is that some of the customs long obsolete in the European traditions were still followed there not so long ago, the beliefs concerning caul, for example. The feeding of placenta to women for curing sterility is also remarkable. Still, I cannot consider this method so characteristic to the ErzaModvinians only, assuming that it is existing but probably not recorded in the tradition of other peoples. It might appear that several folk beliefs and customs have survived longer among the Orthodox peoples than the Lutheran; still, the concepts related to pregnancy (such as startling 'defects' and marks) have survived longer in Estonia than in Ingria and, particularly in Mordvinia. The custom of Sabajevo and Povodimovo to appoint young children the godparents of a new-born child has no explanation. 


\section{Comments}

${ }^{1}$ Krestiama or krestiamo - 'to baptise'

${ }^{2}$ The larger pies were called salmapriaaka.

\section{References}

Balov, A. 1890. Rozhdenie i vospitanie detei v Poshekhonskom uiezde, Jaroslavskoi g. Etnograficheskoe obozrenie, 3, 90-114.

Beliaieva, N. 1982. Rodil'nye obriady mordvy-mokshiAtiurievskogo raiona Mordovskoi ASSR (konets XIX - nachalo XX v.) Etnokul'turnye protsessy v Mordovii. Trudy Nauchno-issledovatel'skogo instituta iazyka, literatury, istorii i ekonomiki pri Sovete Ministrov Mordovskoi ASSR. Vyp. 71. Saransk, 51-62.

Boecler, J. W. \& Kreutzwald, Fr. R. 1854. Der Ehsten abergläubische Gebräuche, Weisen und Gewohnheiten von Johann Wolfgang Boecler, weiland Pastor zu Kusal in Ehstland und des Consistorii in Reval asessor. Mit auf die Gegenwart bezüglichenAnmerkungen beleuchtet von Dr. Fr. R. Kreutzwald. St. Petersburg.

Chursin, G. 1956. Svad'ba i brak. Rodil'nye obychai. Materialy po etnografii Abkhazii. Suhhumi, 159-206.

Dbar, S. 1984. Traditsionnye priomy ukhoda za maloletnimi det'mi u abkhazov (konets XIX - nachalo XX vv.) Etnicheskaia kul'tura: dinamika osnovnykh elementov. Moskva, 164-174.

Eisen, M. J. 1928. Vahetatud lapsed.Eesti Kirjandus XXII. Tartu, 430-438.

Fedianovich, T. 1979. Mordovskie narodnye obriady, sviazannye s rozhdeniem rebionka. Sovetskaia etnografia, 2, 79-89.

Fedianovich, T. 1981. Rodilnye obriady u mordvy (k ikh kolichestvennoi kharakteristike). Traditsionnye $i$ novye obriady $v$ bytu narodov SSSR. Moskva, 118-124.

Granqvist, H. 1947. Birth and childhood among the Arabs. Studies in a Muhammadan village in Palestine. Helsingfors.

Grundström, H. 1953. Lappalaisten uskomuksia äidistä ja lapsesta. Virittäjä, 82-92.

Grünthal, J. 1924. Eesti rahvameditsiin, eriti sünnituse ning naistehaiguste puhul ja laste arstimisel, vanavara valgustusel. Eesti Kirjandus XVIII: 299-308, 334-347, 386-395, 443-453, 475491. 
Haruzina, V. 1906. Neskol'ko slov o rodil'nykh i krestinnykh obriadakh i ob ukhode za det'mi v Pudozhkom u. Olonetsk. g. Etnograficheskoe obozrenie, 1-2, 88-95.

Harva, U. 1933. Altain suvun uskonto. Porvoo \& Helsinki.

Harva, U. 1935. Varsinais-Suomen henkistä kansankulttuuria. Varsinais-Suomen historia III: 1. Porvoo.

Heikinmäki, M.-L. 1968. "Pirttipussia" kannettiin. Kalevalaseuran vuosikirja, 48, 222-243.

Hovorka, O. v. \& Kronfeld, A. 1909. Vergleichende Volksmedizin. Bd. II. Stuttgart.

Itkonen, T. I. 1948. Suomen lappalaiset vuoteen 1945, 1. Porvoo. Jordan, B. 1978. Birth in four cultures. Montreal.

Jung, J. 1879. Eesti rahva vanast usust, kombedest ja juttudest. Kodumaalt, nr 6. Tartu.

Karely 1983 = Karely Karel'skoi ASSR. Petrozavodsk.

Koivu, L. 1962. Syntymään liittyvistä enteistä. Kalevalaseuran vuosikirja, 42, 301-319.

Leskinen, E. \& Syrjänen-Kaukoranta, L. 1939. Ilomantsin itäkylien ruokataloudesta ym. naisten askareista. Kansantieteellisiä muistiinpanoja Ilomantsin itäkylistä. Kansantieteellinen arkisto III. Forssa, 193-216.

Loorits, O. 1932. Die Geburt in der livischen Volksüberlieferung. Verhandlungen der Gelehrten Estnischen Gesellschaft XXVI. Tartu, 131-169.

Luce, J. W. L. von 1827. Wahrheit und Muthmassung. Beytrag zur ältesten Geschichte der Insel Oesel. Pernau.

Mashurko, M. 1894. Iz oblasti narodnoi fantazii i byta Tiflisskoi i Kutaisskoi gub. Sbornik materialov dlia opissania mestnostei $i$ plemen Kavkaza. Vyp. 18. Tiflis, 228-410.

Maslova, G. 1984. Narodnaia odezhda v vostochnoslavianskikh traditsionnykh obychaiakh i obrjadakh XIX - nachala XX v. Moskva.

Melik-Shakhnazarov, J. 1893. Iz poverii, predraszsudkov i narodnykh primet armian Zangezurskago uiezda. Sbornik materialov dlia opissania mestnostei i plemen Kavkaza. Vyp. 17. Tiflis, 193-201.

Mikkor, M. 1994. Surmaga seotud tavadest ersamordva külades Sabajevos ja Povodimovos. Eesti Rahva Muuseumi aastaraamat XL. Tartu, 153-189.

Mikkor, M. 1996. Rasedusega seotud uskumustest Kaukaasia eestlastel. Vaga vares. Pro folkloristica IV. Tartu, 65-72. 
Mikkor, M. 1998a. Sünnitusabist Musta mere ranniku eesti külades. Akadeemia, 5.

Mikkor, M. 1998b. Ersade sünnikombestikust Sabajevo ja Povodimovo külas. Eesti Rahva Muuseumi aastaraamat XLII. Tartu, 53-78.

Mikkor, M. 1999a. Soikkola isurite ja Kurgola soomlaste sünnikombestikust. Akadeemia, 5, 975-1086.

Mikkor, M. 1999b. Sünnijärgse ajaga seotud toimingutest Kaukaasia eestlastel.Eesti Rahva Muuseumi aastaraamat XLIII. Tartu, 133-170.

Murathan, V. 1937. Obychai, sviazannye s rozhdeniem i vospitaniem rebionka u siriitsev SSSR. (Po materialam ekspeditsii 19281929 g. k siriitsam Armjanskoi SSR.) Sovetskaia etnografia, nr. 4, 61-84.

Päss, E. 1938.About the Customs at Childbirth among the Ingers and the Votes. Verhandlungen der Gelehrten Estnischen Gesellschaft, Bd. XXX. Tartu, 538-564.

Paulaharju, J. 1929. Pikkulapsen varauksia. Peräpohjan kansantietoutta. Kotiseutu 1, 12-16.

Pchelina, J. 1937. Rodil'nye obytshai u ossetin. Sovetskaia etnografia, 4, 85-103.

Pchelintseva, N. 1987. Narodnye obriady i poveria, sviazannye $\mathrm{s}$ okhranoi zdorovia rebionka u azerbaidzhantsev. Polevye issledovania Instituta etnografii 1983. Moskva, 38-44.

Pelkonen, E. 1931. Über volkstümliche Geburtshilfe in Finnland. (Acta Societatis Medicorum Fennicae Duodecim, Ser. B, Tom. XVI) Helsinki.

Ploss, H. 1884. Das Kind in Brauch und Sitte der Völker. Bd. I. Leipzig.

Popov, G. 1903. Rody. Russkaia narodno-bytovaia meditsina po materialam etnograficheskago biuro kniazia $V$. N. Tenisheva. S. Peterburg, 325-362.

Redko,A. 1899. Nechistaia sila v sud'bakh zhenshchiny-materi. Etnograficheskoe obozrenie, 1-2, 55-131.

Ruotsalainen, A. 1950. Onnenlakki ja onnenpaita kansanperinteessä. Kalevalaseuran vuosikirja, 30, 163-190.

Ruuttu, M. 1931. Kansantapoja ja -uskomuksia Karjalan kannaksen itäosissa. Kansatieteellisiä kuvauksia 3. Suomalaisen Kirjallisuuden Seuran toimituksia 186. Helsinki. 
Sartori, P. 1910. Sitte und Brauch. Handbücher zur Volkskunde. Bd. 5. Leipzig.

Sohlman, A. 1933. Pälkäneen naimapuuhista sekä syntymään ja kuolemaan liittyvistä tavoista ja uskomuksista. Kotiseutu, 153167.

Soloviova, L. 1983. Rodil'naia obriadnost' u gruzin (konets XIX nachalo XX v.). Polevye issledovania Instituta etnografii 1979. Moskva, 123-128.

Soloviova, L. 1987. Materialy po obriadnosti detskogo tsikla u gruzii Adzharii. Polevye issledovania Instituta etnografii 1983. Moskva, 29-38.

Sumtsov, N. 1880. O slavianskikh narodnykh vozzreniakh na novorozhdionnogo rebionka. Zhurnal Ministerstva Narodnogo Prosveshchenia, ch. CCXII. S.-Peterburg, 68-94.

Talve, I. 1959. Suomen varpaiset ja sen tausta. Scripta Ethnologica 2. Verba decent. Suomalaisen Kirjallisuuden Seuran toimituksia 263. Turku, 1-20.

Talve, I. 1979. Suomen kansankulttuuri: historiallisia päälinjoja. Suomalaisen Kirjallisuuden Seuran toimituksia 355. Helsinki \& Mikkeli.

Virtaranta, P. 1961. Tverin karjalaisten entistä elämää. Porvoo \& Helsinki.

Väisänen,A. O. 1924. Syntymä, lapsuus ja kuolema. Setukaisten tapoja ja uskomuksia. Kalevalaseuran vuosikirja, 4, 193-223.

Wiedemann, F. J. 1876. Aus dem inneren und äusseren Leben der Ehsten. St. Petersburg.

Zelenin, D. 1927. Russische (ostslavische) Volkskunde. Berlin \& Leipzig.

\section{Sources and Abbreviations}

$\mathrm{EA}=$ the Ethnographic Archives of the Estonian National Museum.

EA 218: 64-159. Mikkor, M. 1988. Etnograafilisi materjale inimese elutähtpäevadega seotud kombestiku ning peremärkide kohta Mordvast Kotshkurovi raj. Sabajevo külast.

EA 218: 245-370. Mikkor, M., Alatalu, R. 1989. Teateid ersa mordvalaste perekonnakombestiku, kalendritähtpäevade, asus- 
tuse, elatusalade ja muu eluolu kohta (Mordva ANSV Kotshkurovi raj. Sabajevo k. ja Dubjonki raj. Povodimovo k.).

EA 220: 96-201. Mikkor, M. 1988. Inimese elutähtpäevadega seotud kombestikust isuritel ja soomlastel.

EA 234: 278-362. Mikkor, M., Alop, T., Kodar, S. 1987. Teateid Soikkola poolsaare isurite perekonnakombestikust, küladest, rahvakalendrist, saunadest ja rahvameditsiinist. Perekonnakombestik (M. Mikkor).

$\mathrm{ENM}=$ Estonian National Museum.

ERA = manuscript folklore collection of the State Literary Museum (1927-1944) at the Estonian Folklore Archives.

RKM = folklore collection of the Estonian Folklore Archives of the Estonian Literary Museum of the Estonian Academy of Sciences, basically since 1945 . 